\title{
Effects of the Google Meet Assisted Method of Learning on Building Student Knowledge and Learning Outcomes
}

\author{
Agung Setyawan ${ }^{1,2,}$, Nurfina Aznam ${ }^{1}$, Paidi $^{1}$, Tyasmiarni Citrawati ${ }^{2}$, Kusdianto ${ }^{3}$ \\ ${ }^{1}$ Universitas Negeri Yogyakarta, Yogyakarta, Indonesia \\ ${ }^{2}$ Elementary School Teacher Education Department, Faculty of Education, Universitas Trunojoyo Madura, Indonesia \\ ${ }^{3}$ Elementary Education Study Program, Faculty of Teacher Training and Education, Universitas Cendrawasih, Indonesia
}

Received May 13, 2020; Revised July 22, 2020; Accepted August 10, 2020

\section{Cite This Paper in the following Citation Styles}

(a): [1] Agung Setyawan, Nurfina Aznam, Paidi, Tyasmiarni Citrawati, Kusdianto , "Effects of the Google Meet Assisted Method of Learning on Building Student Knowledge and Learning Outcomes," Universal Journal of Educational Research, Vol. 8, No. 9, pp. 3924 - 3936, 2020. DOI: 10.13189/ujer.2020.0809017.

(b): Agung Setyawan, Nurfina Aznam, Paidi, Tyasmiarni Citrawati, Kusdianto (2020). Effects of the Google Meet Assisted Method of Learning on Building Student Knowledge and Learning Outcomes. Universal Journal of Educational Research, 8(9), 3924 - 3936. DOI: 10.13189/ujer.2020.0809017.

Copyright $\odot 2020$ by authors, all rights reserved. Authors agree that this article remains permanently open access under the terms of the Creative Commons Attribution License 4.0 International License

\begin{abstract}
The purpose of this study was to investigate the effect of the Google Meet media-assisted lecture method on building student knowledge and learning outcomes while learning from home (SFH). A quasi-experimental in the form of pretest-posttest control group design was used in this study. The sample was 96 first-year students (70 girls and 26 men; aged between 18-20) in the elementary school teacher education study program at the University of Trunojoyo Madura in the academic year 2019/2020. Researchers involved three intact classes; 1 class randomly selected as an experimental group and 2 classes as a control group. Knowledge Building Test (TMP) and Cognitive Learning Outcomes Test (THB) are administered as a pretest and posttest. The results of the two-way MANOVA revealed that students taught using the Google Meet media-assisted lecture method have posttest scores building knowledge and learning outcomes higher than comparison groups. Therefore, it can be concluded that the method of lectures assisted by Google Meet media has a significant influence on building knowledge and student learning outcomes in lecturing learning strategies in elementary schools.
\end{abstract}

Keywords Lecture Method, Building Knowledge, Learning Outcomes

\section{Introduction}

\subsection{Google Meet Media Assisted Lecture Method}

Lecture is a method commonly used by educators in learning activities to build student knowledge and learning outcomes. Learning activities require direct communication between educators and students so that the transfer of knowledge in building knowledge and learning outcomes can be well-formed so that the character of students can be directed through the guidance of educators. Components that cannot be separated between schools as learning spaces, educators as educators and students as students in building knowledge and learning outcomes (Barreyro, Injoque-Ricle, Formoso \& Burin, 2019).

The lecture method offers advantages through educator control in learning and shortcomings in the form of passive students and educators as dominant speakers (Paris, 2014). The lecture method provides an advantage for educators in managing classes with many students in one study (Stearns, 2017). The lecture method is more dominant in teaching the delivery of learning material, question and answer between educators and students as part of the process of building knowledge and learning outcomes (Van der Steen dan Van Frissen, 2017). One of the supports in the lecture method is the process of reading in which reading is a supporting factor for students in building knowledge and learning outcomes (Fisher, Ros \& Grant, 2010). 
In the era of the industrial revolution 4.0 had an impact on various aspects one of which was education. The development of new information and knowledge is always spread easily and can be accessed by anyone in need. The education system requires new adaptation with changes in the industrial revolution 4.0. Educators always adapt to information technology so that learning objectives can be achieved (Shukla, Raghuwansh, 2019; Willett, Brown, Danzy-Bussell, 2019; Hamilton, Suda, Heidel, McDonough, Hunt, Franks, 2020). The availability of various services to learn to use technology (online learning) makes it easier for lecturers and students to achieve learning goals, one of which is Google meet. Online learning has a positive impact on learning (Parsazadeh, Zainuddin, Ali, \& Hematian, 2013; Asiry, 2017; Zulfikar, Muhidin, Pranoto, Suparta, Trisetyarso, Abbas, \& Kang, 2019).

Beginning in 2020 is a year beyond all human's expectations. Coronavirus (Covid-19) until 11 April 2020 infected 1,727,506 people and caused the death of 105,722 people in the world (American Library Associacion, 2020). The Covid-19 Pandemic impacts all countries in various important aspects including education. Education in Indonesia is also affected by this pandemic. The role of the government in saving Indonesian education with a variety of policies through the study from home (SFH) policy has shifted the form of learning that was previously conventional to online learning. The new interactive approach through the media application Google Meet makes new knowledge and experience different both by educators and students. Different knowledge and experience are gained through new interactive approaches (Borges \& Mello-Carpes, 2015). One of the responsibilities of schools is to build knowledge and student learning outcomes and skills (Mercer, 2016). Students study at home through applications that have been agreed upon by educators and students. The learning room component that was originally a classroom in the school environment has shifted to the Google Meet application room. Google meet is an interactive and alternative media used for online learning. Google Meet Assist Educators use the lecture method in indirect learning activities. Interactive learning is expected to help students in building knowledge and learning outcomes (Roscoe, 2014).

Basic skills in the use of media aids during SFH in Indonesia are the main requirements for educators and students in communication as well as the delivery of material to build student knowledge and learning outcomes. In the application of learning methods, basic skills are the main requirements to facilitate building knowledge and learning outcomes (Cabero, Pinero \& Reyes, 2018). One of the supports in online learning is student books. In addition to educators delivering material, it is also expected that students will have the habit of reading in each context to support the process of building knowledge and learning outcomes. The habit of reading and bringing books closer to students is a natural way to encourage building knowledge and learning outcomes and facilitate the learning process (Jimenez, Manzanal \& Baridon, 2019). Assistance by parents in reading books when the distance learning process helps students be more creative and innovative to follow the learning process optimally (Medina \& Nagamine, 2019). The challenges faced by educators are oriented towards changing planning instruments in learning that are significant for managing various things including building knowledge and learning outcomes (Tobon, Prieto \& Fraile, 2010).

\subsection{Building Knowledge}

Aspects of building knowledge were adapted by researchers from John Piaget, namely building understanding; Build a scheme and adjust to the scheme; Organizing experience; Equilibration and Stages of development (Santrock, 2011). The Build understanding is the process of building knowledge and understanding of something that is processed through the five senses to produce a scheme (Joubert \& Wishart, 2012; Robson \& Boray, 2016; Hipkiss \& Varga, 2018; Meyer \& Norman, 2020). The Build a scheme and adjust to the scheme is the process of assimilating the scheme with information and experience and accommodation in adjusting to the scheme to consider information and experience (Rustiadi, 2015). The Organizing experience is part of a higher thought process (Ahmad, Alias, Mohamad, \&Yusof, 2019). The Equilibration and Stages of development is a process of cognitive conflict about the schemes that are being built with the information and experiences they have to create a process for change (Muthivhi, 2015).

\subsection{Learning Outcomes}

The need to achieve learning outcomes in learning activities both physical, mental, knowledge, and emotional in the responsibility of the tasks given. The researcher adopts from bloom in the assessment of student abilities that are tailored to the learning objectives and focuses on aspects of student cognitive learning outcomes. The learning outcomes refer to the course objectives that contain aspects is analyzing, evaluate, and create.

\subsection{The Aim of the Study}

This research focuses on the effect of the Google Meet media-assisted lecture method on building student knowledge and learning outcomes. The research question is whether the method of lectures assisted by Google Meet media affects building student knowledge and learning outcomes. 


\section{Materials and Methods}

\subsection{Research Design}

Table 1. A quasi-experimental pretest-posttest control group design

\begin{tabular}{|c|c|c|c|}
\hline Groups & Pretest & Process & Posttest \\
\hline Experiment & $\begin{array}{c}\text { Knowledge Building Test (TMP) } \\
\text { Cognitive Learning Outcomes Test } \\
\text { (THB) }\end{array}$ & $\begin{array}{c}\text { Google Meet's assisted lecture } \\
\text { method }\end{array}$ & $\begin{array}{c}\text { Knowledge Building Test (TMP) } \\
\text { Cognitive Learning Outcomes Test } \\
\text { (THB) }\end{array}$ \\
\hline Control I & $\begin{array}{c}\text { Knowledge Building Test (TMP) } \\
\text { Cognitive Learning Outcomes Test } \\
\text { (THB) }\end{array}$ & $\begin{array}{c}\text { Whatsapp-assisted lecture } \\
\text { method }\end{array}$ & $\begin{array}{c}\text { Knowledge Building Test (TMP) } \\
\text { Cognitive Learning Outcomes Test } \\
\text { (THB) }\end{array}$ \\
\hline Control II & $\begin{array}{c}\text { Knowledge Building Test (TMP) } \\
\text { Cognitive Learning Outcomes Test } \\
\text { (THB) }\end{array}$ & $\begin{array}{c}\text { Schoology-assisted lecture } \\
\text { method }\end{array}$ & $\begin{array}{c}\text { Knowledge Building Test (TMP) } \\
\text { Cognitive Learning Outcomes Test } \\
\text { (THB) }\end{array}$ \\
\hline
\end{tabular}

In this study, we adopted a quasi-experimental pretest-posttest control group design (can be seen in Table 1). The researcher uses three intact classes; 1 class randomly selected as an experimental group and 2 classes as a control group. The experimental group students used the Google Meet media assisted lecture method. Then, the control group students I use the Whatsapp group assisted lecture through the voice recorder, and the control group II students use the Schoology assisted lecture method. Before treatment, all classes carried out a pretest, and posttest was given after the treatment. Data is collected from March 17 to April 24, 2020.

\subsection{Sample}

The sample was 96 first-year students (70 female and 26 male; aged between 18-20) in the education program of elementary school teachers, faculty of education, University of Trunojoyo Madura. Next, the researcher randomly chooses the classes used as the experimental class and the control classes using cluster random sampling.

\subsection{Instruments}

\subsubsection{Knowledge Building Test (TMP)}

The knowledge building test instrument was developed and adapted by John Piaget (Santrock, 2011). There are 4 aspects that testers are build understanding; Build a scheme and adjust to the scheme; Organizing experience; Equilibration and Stages of development. The form of the questions given is in the form of 7 written test questions. The content validity coefficient for each item has a value of 1.00 so that the question is feasible to use. Each item has a maximum score of 5 and a minimum score of 1 . The length of time to take this test is 60 minutes.

\subsubsection{Cognitive Learning Outcomes Test (THB)}

The development of instruments was adapted from the cognitive domain which contained aspects of analyzing, evaluating, and creating following learning objectives (Bloom, 1956; Junoh \& Muhamad, 2012; Julistiawati \& Yonata, 2013; Faisal, 2015). The form of the questions given is in the form of essay questions. There are 14 items for each item developed from the aspects of analyzing, evaluate, and create. Each item has a maximum value of 1 and a minimum of 0 . The coefficient of the validity of the contents of the questions is worth 1.00 so it is feasible to be used as a test. The scoring method by adding the correct questions multiplied by 100 divided by the number of questions. The length of time provided in working on this problem is 60 minutes.

The technique used by researchers in this study is a test technique in the form of a written test. Instruments used by researchers in the form of grids, test sheets, and assessment rubrics (building knowledge and cognitive learning outcomes) were given at the pretest and posttest. The pretest and posttest results are used by researchers to see the gain scores of the experimental class and the control class. Written tests are given in the form of description by considering aspects of building knowledge and cognitive learning outcomes.

\subsection{Procedures}

The researcher conducted an inductive study related to the problem that he wanted to solve in the learning strategy courses in Elementary Schools. Then we identified the problem in the form of Building Student Knowledge and Learning Outcomes. Furthermore, researchers conducted a literature study from various relevant sources, formulated research hypotheses, determining operational definitions and variables. Our next step is to make a research plan that includes identifying external variables that are not needed but allowing contamination in the data collection process, determining how to control them, choosing the right research design, determining the population, sample and choosing the number of research subjects, dividing them into control groups and experiments, making appropriate instruments and conducting pilot studies to meet the 
required data collection requirements, identifying data collection procedures, and determining hypotheses. Next, we conduct experiments and collect rough data from the experimental process carried out. Next, we do the organization and description of the data according to predetermined variables and then analyze it. Our final step is to make a research report.

The learning strategy courses in Elementary Schools consist of 6 discussion topics, namely the nature of learning in elementary schools; Basic concepts and principles of learning; Basic teaching skills for elementary school teachers; The PAIKEM approach in primary school; Learning methods; Innovative learning model. In total there are 8 meetings in this course, and the time required is $2 \times 40$ minutes at each meeting. Treatment is carried out for 6 weeks. Each experiment and control class was taught by 1 lecturer in the age range of 30-35 years.

\subsubsection{Instructions for using the Google Meet Assistance Method}

The learning process goes through 3 stages: preparation, implementation, and closing. In the preparation stage, the lecturer formulates the objectives to be achieved at the meeting, determines the subject matter to be delivered, and prepares tools in the form of google meet media. Preparation in the components of both the laptop camera and microphone so that what is conveyed can be heard clearly by the audience. At the implementation, the stage consists of opening, and presentation of material by lecturers through the Google Meet application. The concluding phase is filled with a summary of the subject matter that has been learned so that students can recall the material presented.

\subsubsection{Instructions using Whatsapp-assisted lecture method}

The learning process goes through 3 stages: preparation, implementation, and closing. In the preparation stage, the lecturer prepares the objectives to be achieved as well as the material at the meeting. Prepare media in the form of Whatsapp group (class) to facilitate communication. Lecturers and students agree on the time of learning activities through the Whatsapp group. At the implementation stage in the delivery of material lecturers which provide recorded material for students to listen to in the group. Communication of questions and responses is done through the Whatsapp group via voice recorder or in writing in the Whatsapp group. In the closing stage, the lecturer gives a recording in the form of a summary of the subject matter being studied so that it can be used as study material outside the lecture schedule.

\subsubsection{Instructions use the Schoology-assisted lecture method}

The learning process goes through 3 stages: preparation, implementation, and closing. In the preparation stage, both the initial planning of lecturers and students have created a discussion room for one class so that it can be scheduled when learning is done. Besides, lecturers also share the study material to be submitted in the material folder. At the implementation stage in the Schoology group, the lecturer gives a recorded material at the agreed-upon lecture, besides the lecturer also gives time for written question and answer activities in the discussion room. In the closing activity, the lecturer delivered a summary of what was learned at the meeting.

\subsection{Data Analysis}

Before conducting parametric statistical tests, the Kolmogorov-Smirnov and Levene tests were used to check the normality and homogeneity of the data at the 0.05 significance level. The assumption test results show that the Kolmogorov-Smirnov One-Sample Test results on aspects of building knowledge and cognitive learning outcomes show significance above 0.05 so that the data concluded are normally distributed. Likewise, the Levene test results showed significance above 0.05 so that the data was concluded to be homogeneous. The test results can be seen in Table 2, Table 3, and Table 4. Furthermore, to determine the differences in influence between groups, researchers used a multivariant test analysis (MANOVA). Data were analyzed using SPSS 23 application.

Table 2. Normality of building knowledge

\begin{tabular}{|c|c|c|c|}
\hline \multicolumn{4}{|c|}{ One-Sample Kolmogorov-Smirnov Test } \\
\hline \multicolumn{2}{|c|}{} & Pretest & Posttest \\
\hline \multirow{2}{*}{ Normal Parameters ${ }^{\mathrm{a}}$} & Mean & 32 & 32 \\
\cline { 2 - 4 } & Std. Deviation & 36.04 & 67.08 \\
\hline \multirow{2}{*}{ Most Extreme } & Absolute & .16 & 7.12 \\
\hline \multirow{2}{*}{ Differences } & Positive & .10 & .19 \\
\cline { 2 - 4 } & Negative & -.16 & -.23 \\
\hline \multicolumn{2}{|c|}{ Kolmogorov-Smirnov Z } & .93 & 1.28 \\
\hline \multicolumn{2}{|c|}{ Asymp. Sig. (2-tailed) } & .35 & .07 \\
\hline
\end{tabular}

Table 3. Normality of cognitive learning outcomes

\begin{tabular}{|c|c|c|c|}
\hline \multicolumn{4}{|c|}{ One-Sample Kolmogorov-Smirnov Test } \\
\hline \multicolumn{2}{|c|}{} & Pretest & Posttest \\
\hline \multirow{2}{*}{ Normal Parameters ${ }^{\mathrm{a}}$} & Mean & 32 & 32 \\
\cline { 2 - 4 } & Std. Deviation & 28.57 & 62.50 \\
\hline \multirow{2}{*}{ Most Extreme } & Absolute & .22 & 1.63 \\
\hline \multirow{2}{*}{ Differences } & Positive & .22 & .14 \\
\cline { 2 - 4 } & Negative & -.16 & -.12 \\
\hline \multicolumn{2}{|c|}{ Kolmogorov-Smirnov Z } & 1.24 & .81 \\
\hline \multicolumn{2}{|c|}{ Asymp. Sig. (2-tailed) } & .09 & .52 \\
\hline
\end{tabular}


Table 4. Test of Homogeneity of Variances

\begin{tabular}{|c|c|c|c|c|}
\hline \multicolumn{5}{|c|}{ Test of Homogeneity of Variances } \\
\hline & $\begin{array}{c}\text { Levene } \\
\text { Statistic }\end{array}$ & df1 & df2 & Sig. \\
\hline Knowledge Building & 1.27 & 2 & 93 & .29 \\
\hline $\begin{array}{c}\text { Cognitive Learning } \\
\text { Outcomes }\end{array}$ & .32 & 2 & 93 & .73 \\
\hline
\end{tabular}

\section{Findings}

The implementation of this experiment is to find out the effectiveness of the Google Meet media-assisted lecture method on aspects of building knowledge and cognitive learning outcomes. Researchers ensure the implementation of learning using the lecture method assisted by Google Meet media with a very good category with an average of $100 \%$ in meetings I to meetings VI. Next, the researchers analyzed construct knowledge and cognitive learning outcomes.

\subsection{Improved Pretest and Posttest Scores on Building Knowledge}

The results of the analysis build knowledge that the average score of the posttest on the Google Meet Group is higher than the average value of the control class. The average gain on the Google Meet Group was 0.57, while the Whatsapp Group was 0.47 and the Schoology Group was 0.38. The gain was obtained through SPSS 23. Recapitulation of knowledge building scores is presented in Table 5 below.

In the table, it can be seen that there is an increase in aspects of building knowledge for each aspect. This increase is indicated by the positive gain in each aspect. There is an increase in the experimental class and the control class and show that the acquisition of the experimental class is higher than the control class. The results of the acquisition of knowledge building scores are supported by the results of the pretest and posttest analysis of the threshold value for passing which is 70 . The results are presented in Table 6 below.
Pretest results show that building knowledge in the experimental class and the control class did not reach the graduation threshold. While the Google Meet Group posttest results from 25 students score equal or more than the graduation threshold, Whatsapp Group there are 15 students who score equal or more than the graduation threshold, Schoology Group there are 14 students who score equal or more than the threshold pass limit. This shows the number of students who meet the graduation threshold in the experimental class is higher than the control class.

\subsection{Improved Pretest And Posttest Scores on Cognitive Learning Outcomes}

The cognitive learning analysis results obtained from the average pretest and posttest scores on the Google Meet Group are higher than Whatsapp Group, and Schoology Group. The high value of cognitive learning outcomes through the acquisition of the average gain obtained. The average gain on the Google Meet Group was 0.56, while on the Whatsapp Group it was 0.43, and the Schoology Group was 0.34 . The recapitulation of cognitive learning outcome scores is presented in Table 7 below.

The results of the Google Meet Group cognitive learning outcomes scores are higher than those of the Whatsapp Group, and the Schoology Group is supported by an analysis of the pretest and posttest results on the passing threshold value of 70 . A comparison of the cognitive learning outcomes of the experimental class and the control class is presented in Table 8 below.

The results of the pretest show that no student has reached the minimum threshold to graduate. Posttest results obtained at Google Meet Group 15 students reach the minimum threshold to graduate, Whatsapp Group 9 students reach the minimum threshold to graduate, and Schoology Group 3 students reach the minimum threshold to graduate. These results conclude that the number of students who reach the minimum threshold to pass on the Google Meet Group is higher than the Whatsapp Group and Schoology Group.

Table 5. Recapitulation of scores building knowledge.

\begin{tabular}{|c|c|c|c|c|c|c|c|c|c|}
\hline \multirow{2}{*}{} & \multicolumn{3}{|c|}{ Google Meet Group } & \multicolumn{3}{|c|}{ Whatsapp Group } & \multicolumn{3}{c|}{ Schoology Group } \\
\cline { 2 - 12 } & Pre & Post & Gain & Pre & Post & Gain & Pre & Post & Gain \\
\hline Build an understanding & 54.25 & 80.50 & 0.57 & 74.50 & 77.75 & 0.13 & 66.00 & 77.75 & 0.35 \\
\hline Build a scheme and adjust to the scheme & 46.00 & 80.50 & 0.64 & 34.00 & 72.00 & 0.58 & 46.50 & 74.50 & 0.52 \\
\hline Organizing experience & 22.22 & 61.78 & 0.51 & 14.89 & 56.00 & 0.48 & 32.89 & 52.89 & 0.30 \\
\hline Equilibration and Stages of development & 36.80 & 74.40 & 0.59 & 18.80 & 63.80 & 0.55 & 36.20 & 61.20 & 0.39 \\
\hline
\end{tabular}

Table 6. Completeness results build knowledge based on graduation thresholds

\begin{tabular}{|c|c|c|c|c|c|c|}
\hline \multirow{2}{*}{ Completeness } & \multicolumn{2}{|c|}{ Google Meet Group } & \multicolumn{2}{|c|}{ Whatsapp group } & \multicolumn{2}{c|}{ Schoology Group } \\
\cline { 2 - 6 } & Pretest & Posttest & Pretest & Posttest & 15 & 0 \\
\hline Complete & 0 & 25 & 0 & 17 & 14 \\
\hline Not complete & 32 & 7 & 32 & 18 \\
\hline
\end{tabular}


Table 7. Recapitulation of scores on cognitive learning outcomes

\begin{tabular}{|c|c|c|c|c|c|c|c|c|c|}
\hline & \multicolumn{3}{|c|}{ Google Meet Group } & \multicolumn{3}{c|}{ Whatsapp Group } & \multicolumn{3}{c|}{ Schoology Group } \\
\cline { 2 - 11 } & Pre & Post & Gain & Pre & Post & Gain & Pre & Post & Gain \\
\hline Analyze & 4.33 & 12.33 & 0.08 & 4.33 & 10.67 & 0.07 & 4.67 & 7.50 & 0.03 \\
\hline Evaluate & 10.75 & 21.00 & 0.11 & 12.00 & 20.00 & 0.09 & 10.75 & 16.75 & 0.07 \\
\hline Create & 6.25 & 0.11 & 0.05 & 6.75 & 10.00 & 0.03 & 6.50 & 9.00 & 0.03 \\
\hline
\end{tabular}

Table 8. Completeness of cognitive learning outcomes towards the graduated threshold value

\begin{tabular}{|c|c|c|c|c|c|c|}
\hline \multirow{2}{*}{ Completeness } & \multicolumn{2}{|c|}{ Google Meet Group } & \multicolumn{2}{c|}{ Whatsapp Group } & \multicolumn{2}{c|}{ Schoology Group } \\
\cline { 2 - 7 } & Pretest & Posttest & Pretest & Posttest & Pretest & Posttest \\
\hline Complete & 0 & 15 & 0 & 9 & 0 & 3 \\
\hline Not complete & 32 & 17 & 32 & 23 & 32 & 29 \\
\hline
\end{tabular}

\subsection{Pretest Score Results on Building Knowledge and Learning Outcomes}

Group different tests before treatment using Wilk's Lambda multivariant test on the pretest scores to build student knowledge and learning outcomes. These results can be seen in the following Table 9.

Testing the assumptions before conducting the wilks' Lambda 'multivariate test includes tests of normality and homogeneity of the variance-covariance matrix. Multivariate normality is examined through the chi-square graph and compares the squares mahalonobis distance with the chi-square quantile. Chi-square plot graph of sample class data is presented in Figure 1 below:

Table 9. Summary of pretest and posttest results before treatment

\begin{tabular}{|c|c|c|c|c|c|c|}
\hline \multirow{2}{*}{ Descriptive statistics } & \multicolumn{2}{|c|}{ Google Meet Group } & \multicolumn{2}{|c|}{ Whatsapp Group } & \multicolumn{2}{c|}{ Schoology Group } \\
\cline { 2 - 7 } & MP & HB & MP & HB & MP & HB \\
\hline Number of students & 32 & 32 & 32 & 32 & 32 & 32 \\
\hline Average value & 39.58 & 30.35 & 36.56 & 32.36 & 45.93 & 31.69 \\
\hline The highest score & 56.67 & 50.00 & 50.00 & 50.00 & 56.67 & 57.14 \\
\hline Lowest value & 23.33 & 14.29 & 23.33 & 14.29 & 30.00 & 14.29 \\
\hline Standard deviation & 8.24 & 9.07 & 8.85 & 6.53 & 6.59 & 8.86 \\
\hline
\end{tabular}

Note: MP: Building knowledge; HB: Learning outcomes

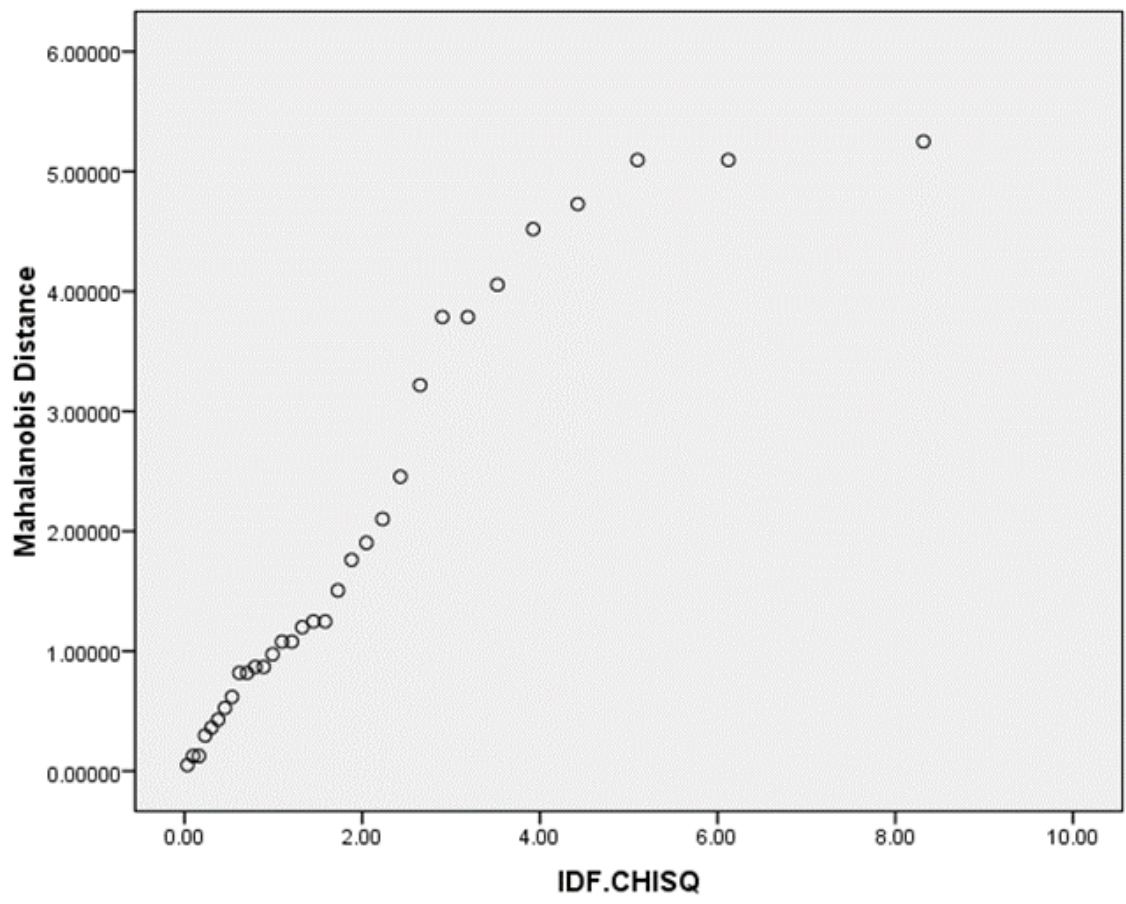



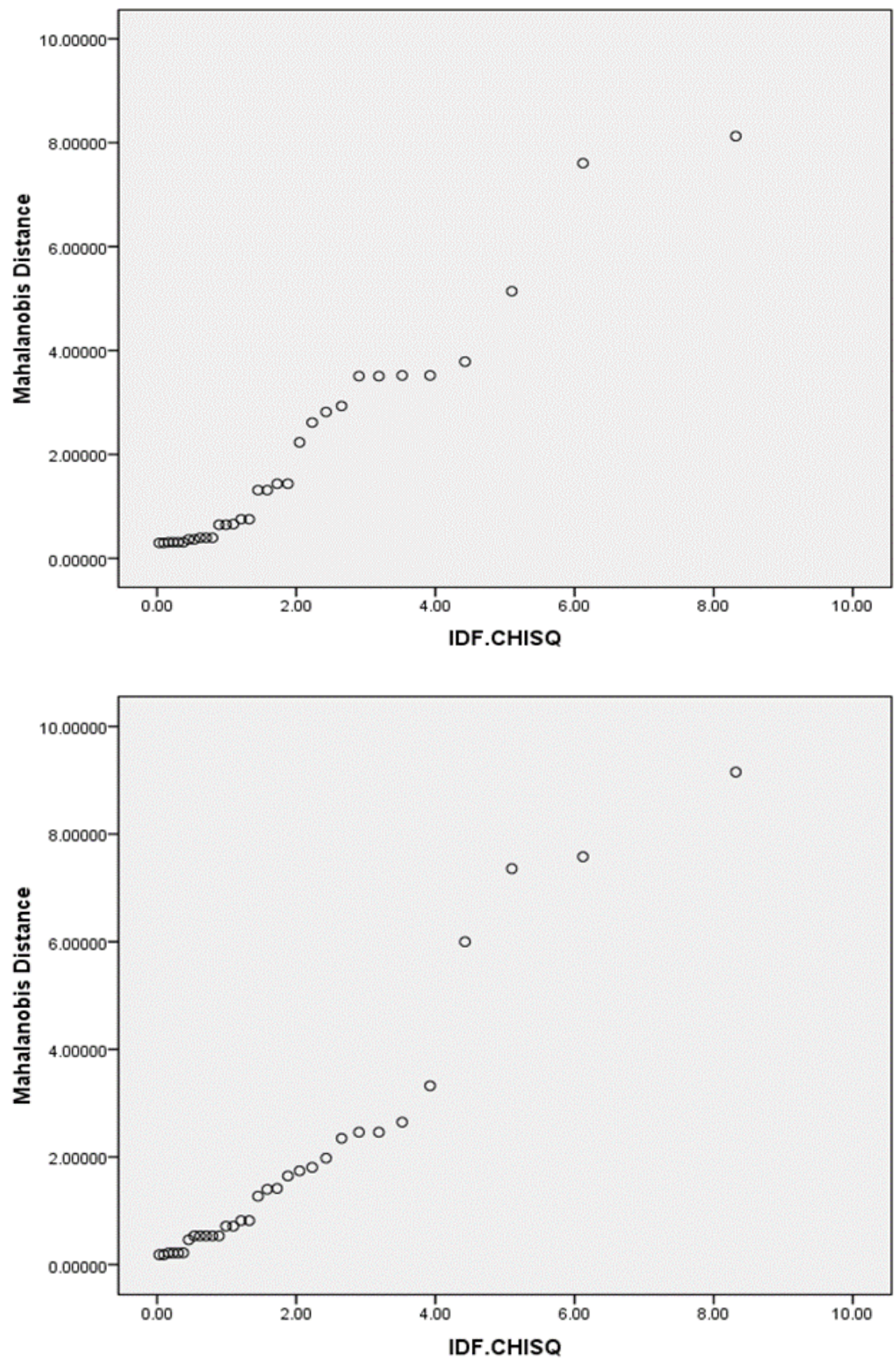

Figure 1. Chi-square plot graph of sample (Google Meet Group, Whatsapp Group, and Schoology Group)

The figure shows that the lines tend to be straight so that it is concluded that the sample comes from multivariant normally distributed data.

Determination of the variance-covariance matrix homogeneity using the Box ' $\mathrm{M}$ Test is presented in Table 10 below.

Table 10. Box 'M test results for normalized gain scores

\begin{tabular}{|c|c|c|c|c|}
\hline & Value & $\mathrm{F}$ & Sig. & conclution \\
\hline $\begin{array}{c}\text { Box 'M } \\
\text { test }\end{array}$ & 7.66 & 1.24 & 0.28 & Ho accepted \\
\hline
\end{tabular}

The box's $M$ value indicates the number 7.66 with a significance value of 0.28 . The significance value is greater than 005 . It was concluded that the variance-covariance matrix originated from a homogeneous population.

After the sample is declared normal and homogeneous, multivariant tests are performed to determine the significance of group differences from building knowledge and student learning outcomes both in the experimental class and the control class. Multivariant test results can be seen in the following Table 11 . 
Table 11. Multivariant test results of the normalized gain score

\begin{tabular}{|c|c|c|c|c|}
\hline & Value & F & Sig. & conclution \\
\hline $\begin{array}{c}\text { Wilk's } \\
\text { Lambda }\end{array}$ & 0.30 & 1.48 & 0.00 & Ho accepted \\
\hline
\end{tabular}

Based on the table, the significance value in the Wilk's Lambda test was 0.00 (Sig. <0.05) so that Ho was rejected. It can be concluded that there are significant differences in the average building knowledge and student learning outcomes of the experimental class and the control class before treatment.

\subsection{Posttest Score Results on Building Knowledge and Learning Outcomes}

The data used by researchers in the analysis of group different tests after treatment is a gain score. The basis of this use is Wilk's Lambda's multivariant test results on the value of the pretest building knowledge and student learning outcomes of the experimental class and the control class. The results of the normalized gain score can be seen in the following Table 12.
Table 12. Summary of the normalized gain scores pretest and posttest results after treatment

\begin{tabular}{|c|c|c|c|c|c|c|}
\hline \multirow{2}{*}{$\begin{array}{c}\text { Descriptive } \\
\text { statistics }\end{array}$} & \multicolumn{2}{|c|}{$\begin{array}{c}\text { Google Meet } \\
\text { Group }\end{array}$} & \multicolumn{2}{c|}{$\begin{array}{c}\text { Whatsapp } \\
\text { Group }\end{array}$} & \multicolumn{2}{c|}{$\begin{array}{c}\text { Schoology } \\
\text { Group }\end{array}$} \\
\cline { 2 - 7 } & $\mathrm{MP}$ & $\mathrm{HB}$ & $\mathrm{MP}$ & $\mathrm{HB}$ & $\mathrm{MP}$ & $\mathrm{HB}$ \\
\hline $\begin{array}{c}\text { Number of } \\
\text { students }\end{array}$ & 32 & 32 & 32 & 32 & 32 & 32 \\
\hline $\begin{array}{c}\text { Average } \\
\text { value }\end{array}$ & 0.57 & 0.56 & 0.47 & 0.44 & 0.37 & 0.26 \\
\hline $\begin{array}{c}\text { The highest } \\
\text { score }\end{array}$ & 0.84 & 0.89 & 0.71 & 0.90 & 0.53 & 0.56 \\
\hline Lowest value & 0.39 & 0.18 & 0.20 & 0.10 & 0.07 & 0.00 \\
\hline $\begin{array}{c}\text { Standard } \\
\text { deviation }\end{array}$ & 0.11 & 0.20 & 0.13 & 0.22 & 0.10 & 0.20 \\
\hline
\end{tabular}

Note: MP: Building knowledge; HB: Learning outcomes

Testing assumptions before carrying out Wilk's Lambda multivariant tests include the normality and homogeneity of the variance-covariance matrix. Multivariant normality was observed using a chi-square graph and comparing the number of squared mahalonobis distances with the number of chi-square quantiles. Chi-square plot graph data for each class is presented in Figure 2 below.

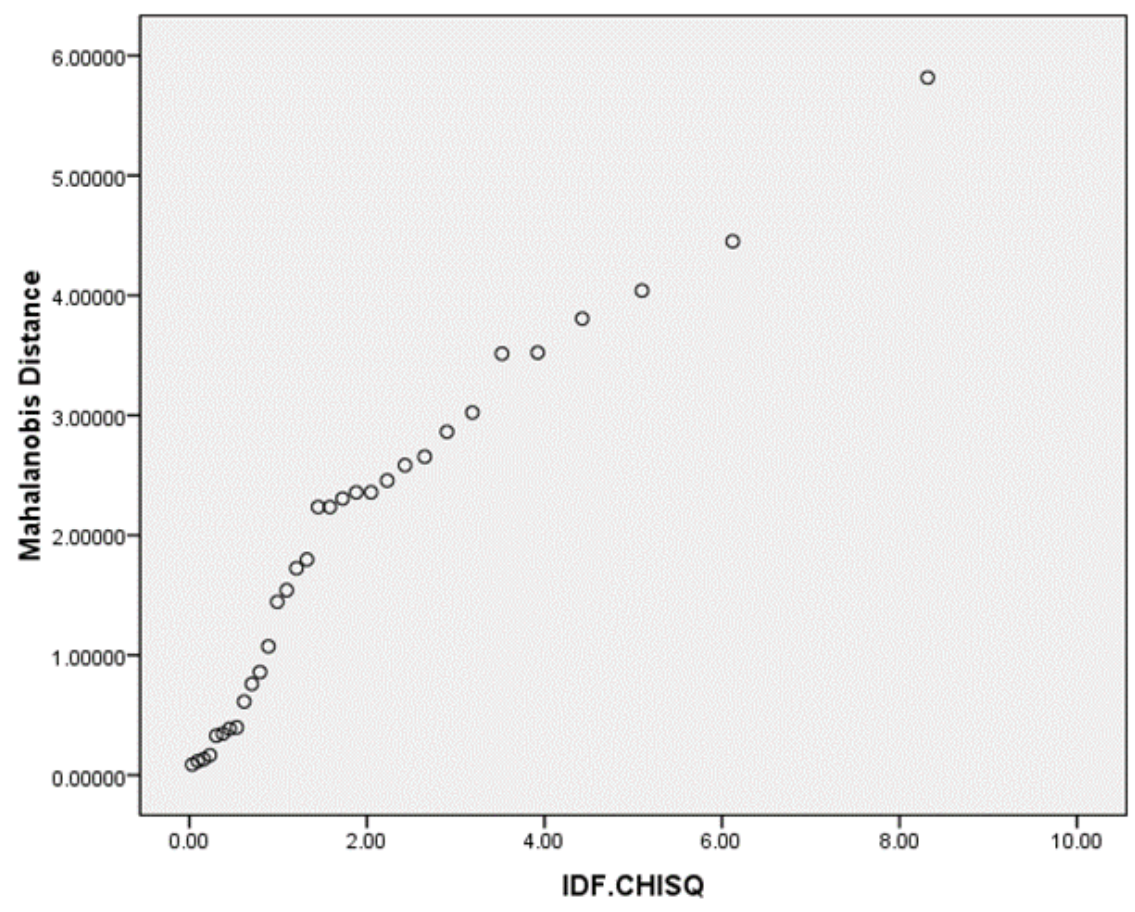



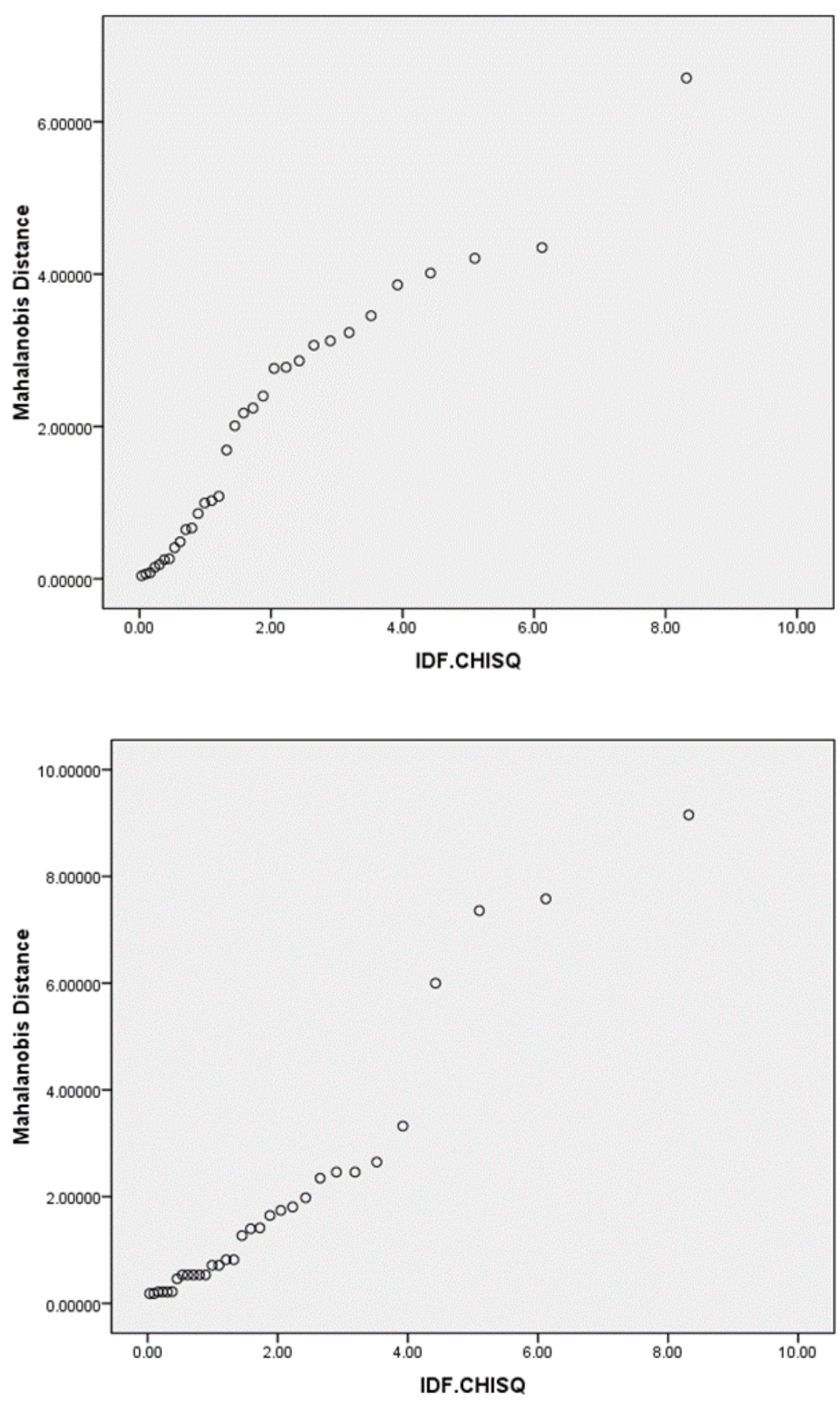

Figure 2. Chi-square plot graph of sample (Google Meet Group, Whatsapp Group, and Schoology Group)

The graph above shows that the lines tend to be straight so that it is concluded that the data samples are normally multivariant distributed.

The homogeneity of the variance-covariance matrix was tested using the Box ' $M$ Test which is presented in Table 13 below. Table 10. Box ' $M$ test results for normalized gain scores
Table 13. Box 'M test results for normalized gain scores

\begin{tabular}{|c|c|c|c|c|}
\hline & Value & $\mathrm{F}$ & Sig. & conclution \\
\hline $\begin{array}{c}\text { Box 'M } \\
\text { test }\end{array}$ & 5.71 & 0.92 & 0.48 & Ho accepted \\
\hline
\end{tabular}

The Box 'M Test results were 5.71 with a significance of 0.48 . The significance value is greater than 0.05 so that it is concluded that the variance-covariance matrix is 
derived from a homogeneous data population.

After the sample data meet the assumptions of multivariate normality and the variance-covariance homogeneity matrix, multivariant tests can be continued to determine the significance of the difference in building knowledge and student learning outcomes in the experimental and control classes. Multivariant test results are presented in Table 14 below.

Table 14. Multivariant test results of the normalized gain score

\begin{tabular}{|c|c|c|c|c|}
\hline & Value & F & Sig. & conclution \\
\hline $\begin{array}{c}\text { Wilk's } \\
\text { Lambda }\end{array}$ & 0.48 & 9.17 & 0.00 & Ho is rejected \\
\hline
\end{tabular}

Wilk's Lambda's significance value is 0.00 below 0.05 so $\mathrm{Ho}$ is rejected. It can be concluded that there are significant differences in the average building knowledge and student learning outcomes in the experimental and control classes after treatment. The results obtained indicate that the Google Meet media-assisted lecture method is effective for improving student knowledge building and learning outcomes.

\subsection{Influence of Instructions on Building Knowledge and Learning Outcomes}

To find out which methods are more effective in terms of each variable, the researcher uses the Tukey test presented in Table 15 below.

Table 15. Further tests to build knowledge and student learning outcomes

\begin{tabular}{|c|c|c|c|c|c|}
\hline $\begin{array}{c}\text { Dependent } \\
\text { Variable }\end{array}$ & \multicolumn{2}{|c|}{ Variabel Independen } & $\begin{array}{c}\text { Mean } \\
\text { Difference }\end{array}$ & $\begin{array}{l}\text { Std. } \\
\text { Error }\end{array}$ & Sig. \\
\hline \multirow{2}{*}{$\begin{array}{l}\text { Building } \\
\text { Knowledge }\end{array}$} & \multirow{2}{*}{$\begin{array}{c}\text { Google } \\
\text { Meet } \\
\text { Group }\end{array}$} & $\begin{array}{c}\text { Whatsapp } \\
\text { Group }\end{array}$ & $0.09 *$ & 0.29 & 0.01 \\
\hline & & $\begin{array}{l}\text { Schoology } \\
\text { Group }\end{array}$ & $0.19 *$ & 0.29 & 0.00 \\
\hline \multirow{2}{*}{$\begin{array}{l}\text { Learning } \\
\text { outcomes }\end{array}$} & \multirow{2}{*}{$\begin{array}{c}\text { Google } \\
\text { Meet } \\
\text { Group }\end{array}$} & $\begin{array}{c}\text { Whatsapp } \\
\text { Group }\end{array}$ & $0.12 *$ & 0.52 & 0.08 \\
\hline & & $\begin{array}{l}\text { Schoology } \\
\text { Group }\end{array}$ & $0.29 *$ & 0.52 & 0.00 \\
\hline
\end{tabular}

Based on the table above, there is a significant difference in the score of building knowledge between Google Meet Group and Whatsapp Group. Google Meet group students get higher knowledge build scores than Whatsapp groups and Schoology groups. Besides, there are significant differences in the scores of learning outcomes between the Google Meet group and the students Whatsapp group and Schoology group. Google Meet group students get a significant score, 0.05 indicates that Google meet group is more effective than the Whatsapp group and Schoology group in terms of building knowledge. Besides, the findings show that the Google Meet group is more powerful in improving learning outcomes compared to the Schoology group. However, no differences were found between the Google Meet group and WhatsApp group concerning learning outcomes.

\section{Discussion and Conclusions}

\subsection{Discussion}

The lecture method using the media help of google meet group is more effective than Whatsapp groups and Schoology groups in terms of building knowledge. The process of learning through Google Meet involves audio and visual aspects where the lecturer delivers the material directly through the media. This is also shown during the learning process where students and lecturers communicate with each other about the material and ask questions about what is not yet understood and can be heard directly by other students so that the process of building student knowledge is higher than Whatsapp groups and Schoology groups.

More effective improvement in learning outcomes in the lecture method using the media help google meet group than Whatsapp group and Schoology group because in the learning process the delivery of information can be done more optimally. Submission of audio and visual together can be observed and listened to by students so that they can work optimally.

The combination of Google Meet's media-assisted lecture methods creates a unique learning experience to achieve learning goals such as building knowledge and student learning outcomes while learning from home (SFH). Online media helps students to find information in supporting learning objectives (Lawson, 2010).

Based on research that has been done, there are several findings related to the application of the Google Meet media-assisted lecture method while studying at home (SFH) to build student knowledge and learning outcomes. Lecturers must prepare and analyze the potential and needs of distance learning. Educators must map the availability of supporting components in learning during SFH. Supporting components in the form of internet networks, mobile, and computer communication devices to support learning.

Learning during SFH must be accompanied by parents to assist students in building knowledge and learning outcomes. Communication through the "Whatsapp group" makes it easy for educators to observe and control various student activities in the process of building knowledge and learning outcomes. Building knowledge and learning outcomes through the lecture method with the limitations of direct meetings between lecturers and students make another impact, namely the presence of students' comfort when learning is accompanied by parents. Emotional relationships are more established between parents and students. Students become easier to understand the material through the guidance of educators and parents.

With the existence of $\mathrm{SFH}$, it makes lecturers and 
students dependent on the communication media. Various direct touches that cannot be replaced in educating ideally the formation of character will be more perfect if there is a direct meeting between educators and students. The time spent in learning is reduced so that to achieve the learning targets lecturers always communicate with parents through Whatsapp groups.

The results of this study are about the effect of the Google Meet media-assisted lecture method while studying at home (SFH) to build student knowledge and learning outcomes. Supports research through teaching and learning of different methods by different educators or researchers. Campus participation, in this case, the study program coordinator in monitoring and assessing learning methods to build student knowledge and learning outcomes to support student learning achievement. Different teaching and learning conducted by lecturers to support the needs of students during the Covid-19 pandemic. Lecturers must discuss more through the method of teaching in teaching.

\subsection{Conclusions}

Some research limitations as part of the conclusion. First, this research includes one method in learning, while it is known that there are many methods in learning that can be used in building student knowledge and learning outcomes. Second, the use of "Google meet" tools is important to facilitate communication and delivery of material by lecturers in building knowledge and student learning outcomes during SFH. Third, the effect of the Caramah method and the variables building knowledge and learning outcomes have been made on self-reported instruments. Fourth, the purpose of this study was to examine the effect of the Google Meet media-assisted lecture method while studying at home (SFH) to build student knowledge and learning outcomes.

The results showed that the lecture method provides a variety of influences, namely the positive impact of SFH learning with parents' assistance in learning so that communication between parents, students, and lecturers can run effectively. Parents and lecturers communicate with each other to help students build knowledge and learning outcomes. The negative impact there are various direct $t$ ouches that cannot be replaced in educating ideally the formation of character will be more perfect if there is a direct meeting between educators and students. Technology can help students in learning and build knowledge and learning outcomes, the presence of educators directly can not be replaced by anything in the formation of student character.

\section{Acknowledgements}

We are very grateful to experts for their appropriate and constructive suggestions to improve this template and to Indonesia Endowment Fund for Education.

\section{REFERENCES}

[1] Ahmad, N. B., Alias, U. F., Mohamad, N., \& Yusof, N. (2019). Principal Component Analysis and Self-Organizing Map Clustering for Student Browsing Behaviour Analysis. Procedia Computer Science, 163, 550-559. doi: https://doi.org/10.1016/j.procs.2019.12.137

[2] American Library Associacion. (2020). Covid-19 coronavirus pandemic. Worldometer.info. Rerieved from: https://www.worldometers.info/coronavirus/

[3] Andrea Lachance, Jere Confrey. (2001). Helping students build a path of understanding from ratio and proportion to decimal notation. The Journal of Mathematical Behavior, 20 (4), 503-526. doi: https://doi.org/10.1016/S0732-3123(02)0 0087-1.

[4] Asiry, M. A. (2017) dental students' perceptions of an online learning. Saudi Dental Journal, 29, 167-170. doi: http://dx.doi.org/10.1016/j.sdentj.2017.03.005.

[5] Barreyro, J., Injoque, I., Formoso, J., \& Burin, D. (2019). Computerized working memory battery (BIMeT-V): Studying the relation between working memory, verbal reasoning and reading comprehension. Trends in Psychology, 27(1), 53-67. https://dx.doi.org/10.9788/tp2019.1-05.

[6] Barreyro, J., Injoque, I., Formoso, J., \& Burin, D. (2019). Computerized working memory battery (BIMeT-V): Studying the relation between working memory, verbal reasoning and reading comprehension. Trends in Psychology, 27(1), 53-67. doi: https://dx.doi.org/10.9788/tp2019.1-05.

[7] Bloom, B. S., etc. (1956). Taxonomy of Educational Objectives: The Classification of Educational Goals, Handbook I Cognitive Domain. New York: Longmans, Green and Co.

[8] Borges, S., \& Mello-Carpes, P. B. (2015). Undergraduate students as promoters of science dissemination: a strategy to increase students' interest in physiology. Advances in Physiology Education, 39(2), 133-136.

[9] Borges, S., \& Mello-Carpes, P. B. (2015). Undergraduate students as promoters of science dissemination: a strategy to increase students' interest in physiology. Advances in Physiology Education, 39(2), 133-136.

[10] Cabero, J., Piñero, R., \& Reyes, M. (2018). Material educativo multimedia para el aumento de estrategias metacognitivas de comprensión lectora. Perfiles educativos, 40(159), 144-159. Recuperado de http://www.scielo. org.mx/scielo.php?script=sci_arttext\&pid=S0185-6982018 000100144\&ln g=es\&tlng=es.

[11] Cabero, J., Piñero, R., \& Reyes, M. (2018). Material educativo multimedia para el aumento de estrategias metacognitivas de comprensión lectora. Perfiles educativos, 40(159), 144-159. Recuperado de http://www.scielo. org.mx/scielo.php?script=sci_arttext\&pid=S0185-6982018 000100144\&ln g=es\&tlng=es. 
[12] Faisal. (2015). Mengintegrasikan revisi taksonomi bloom ke dalam pembelajaran biologi. Jurnal Sainsmat, 4(2), 102-112.

[13] Fisher, D., Ross, D., \& Grant, M. (2010). Building background knowledge. Science teacher, 77(1), 23-26.

[14] Fisher, D., Ross, D., \& Grant, M. (2010). Building background knowledge. Science teacher, 77(1), 23-26.

[15] Hamilton, L. A., Suda, K. J., Heidel, R. E., McDonough, S. L.K., Hunt, M. E., Franks, A. S. (2020). The role of online learning in pharmacy education: A nationwide survey of student pharmacists. Currents in Pharmacy Teaching and Learning. doi: https://doi.org/10.1016/j.cptl.2020.01.026.

[16] Hipkiss, A. M. \& Varga, P. A. (2018). Spotlighting pedagogic metalanguage in Reading to Learn - How teachers build legitimate knowledge during tutorial sessions.Linguistics and Education, 47, 93-104. doi: https://doi.org/10.1016/j.linged.2018.08.002.

[17] Jimenez, L., Manzanal, A., \& Baridon, D. (2019). Reading literacy and metacognition in spanish adult education centre. European Journal for Research on The Education and Learning of Adults. Doi: https://doi.org/10.5093/psed2018a 2.

[18] Jimenez, L., Manzanal, A., \& Baridon, D. (2019). Reading literacy and metacognition in spanish adult education centre. European Journal for Research on The Education and Learning of Adults. Doi: https://doi.org/10.5093/psed2018a 2.

[19] Joubert, M. \& Wishart, J. (2012). Participatory practices: Lessons learnt from two initiatives using online digital technologies to build knowledge. Computers \& Education, 59 (1), 110-119. doi: https://doi.org/10.1016/j.compedu.201 1.09.024.

[20] Julistiawati, R \& Yonata, B. (2013). The Thinking Skill C4, C5, and C6 Level Revision Taxonomy Bloom of Student Class X-3 SMAN 1 Sumenep Through Implemantation Inquiry Learning Model on Main Subject of Electrolyte and Non Electrolyte Solution. UNESA Journal of Chemical Education, 2 (2), 57- 62.

[21] Junoh, A. K., \& Muhamad, W.Z.A.W. (2012). Classification of Examination Marks according to Bloom's Taxonomy by Using Binary Linear Programming. International Confrence on Innovation and Information Management (ICIIM). 36, 20-25.American Library Associacion. (2020). Covid-19 coronavirus pandemic. Worldometer.info. Rerieved From: https://www.worldometers.info/coronavirus/

[22] Lannin, J. K., Barker, D. D., \& Townsend, B. E. (2006). Recursive and explicit rules: How can we build student algebraic understanding?. The Journal of Mathematical Behavior, 25 (4), 299-317. doi: https://doi.org/10.1016/j.jm athb.2006.11.004.

[23] Lawson, A. E. (2020). Teaching inquiry science in middle secondary schools. California: Sage Pub. Inc.

[24] Lawson, A. E. (2020). Teaching inquiry science in middle secondary schools. California: Sage Pub. Inc.

[25] Medina, D., \& Nagamine, M. (2019). Estrategias de aprendizaje de aprendizaje autónomo en la comprensión lectora de estudiantes de secundaria. Propósitos y
Representaciones, 7(2). doi: http://dx.doi.org/10.20511/pyr 2019.v7n2.276.

[26] Medina, D., \& Nagamine, M. (2019). Estrategias de aprendizaje de aprendizaje autónomo en la comprensión lectora de estudiantes de secundaria. Propósitos y Representaciones, 7(2), 134-159. doi: http://dx.doi.org/10.20511/pyr2019.v7n2.276.

[27] Mercer, D. K. (2016). Who is the building leader? Commentary on educational leadership preparation programs for the future. Educational Considerations, 43(4), 6-10.

[28] Mercer, D. K. (2016). Who is the building leader? Commentary on educational leadership preparation programs for the future. Educational Considerations, 43(4), $6-10$

[29] Meyer, M. W. \& Norman, D. (2020). Changing Design Education for the 21st Century. She Ji: The Journal of Design, Economics, and Innovation, 6 (1), 13-49. doi: https://doi.org/10.1016/j.sheji.2019.12.002.

[30] Muthivhi, A. E. (2015). Piaget's Theory of Human Development and Education, Editor(s): James D. Wright. International Encyclopedia of the Social \& Behavioral Sciences (Second Edition). Elsevier, 125-132. doi: https://doi.org/10.1016/B978-0-08-097086-8.92013-0.

[31] Paris, C. (2014). Lecture Method: Pros, cons, and teaching alternatives. Udemy. Rerieved Fromfrom:https://blog.udem y.com/lecture-method//.

[32] Parsazadeh, N., Zainuddin, N.M.M., Ali, R., Hematian, A. (2013). A review on the success factors of e-learning. The second International conference on e-Technologies ond Networks for Development, pp. 42-49.

[33] Robson, B. \& Boray, S. (2016). Data-mining to build a knowledge representation store for clinical decision support. Studies on curation and validation based on machine performance in multiple choice medical licensing examinations. Computers in Biology and Medicine, 73, 71-93. doi: https://doi.org/10.1016/j.compbiomed.2016.02.0 10.

[34] Roscoe, R. D. (2014). Self-monitoring and knowledgebuilding in learning by teaching. Instructional Science: An International Journal of the Learning Sciences, 42(3), 327-351.

[35] Roscoe, R. D. (2014). Self-monitoring and knowledgebuilding in learning by teaching. Instructional Science: An International Journal of the Learning Sciences, 42(3), 327-351.

[36] Rustiadi, S. (2015). Creating Better Education System, Building Stronger Human Capital: A Creative Industries Perspective. Procedia - Social and Behavioral Sciences, 169, 378-386. doi: https://doi.org/10.1016/j.sbspro.2015.01.323

[37] Santrock, J. W. (2011). Masa Perkembangan Anak. Jakarta: Salemba Humatika

[38] Shukla, S., Raghuwansh, B. S. (2019). Online sequential class-specific extreme learning machine for binary imbalanced learning. Neural Networks, 119, 235-248. doi: https://doi.org/10.1016/j.neunet.2019.08.018.

[39] Stearns, S. (2017). Forum: The lecture and student learning. 
What is the place of lecture in student learning today? Communication Education, 66(2), 243-245.

[40] Stearns, S. (2017). Forum: The lecture and student learning. What is the place of lecture in student learning today? Communication Education, 66(2), 243-245.

[41] Tobon, S., Prieto, J., \& Fraile, J. (2010). Secuencias didacticas: aprendizaje y evaluacion de competencias. Mexico: Pearson educationEducation.

[42] Tobon, S., Prieto, J., \& Fraile, J. (2010). Secuencias didacticas: aprendizaje y evaluacion de competencias. Mexico: Pearson educationEducation.

[43] Van der Steen, M., Van T. M., \& Frissen, P. (2017) Learning from experience: From case-based teaching to experience-based learning. Teaching Public Administration,
35, 105-125.

[44] Van der Steen, M., Van T. M., \& Frissen, P. (2017) Learning from experience: From case-based teaching to experience-based learning. Teaching Public Administration, 35, 105-125.

[45] Willett, J., Brown, C., Danzy-Bussell, L. A. (2019). An exploratory study: Faculty perceptions of online learning in undergraduate sport management programs. Journal of Hospitality, Leisure, Sport \& Tourism Education, 25, 100206. doi: https://doi.org/10.1016/j.jhlste.2019.100206.

[46] Zulfikar, A. F., Muhidin, A., Pranoto, Suparta, W., Trisetyarso, A., Abbas, B. S., \& Kang, C. H. (2019). The Effectiveness of Online Learning with Facilitation Method. Procedia Computer Science, 161, 32-40. doi: https://doi.org/10.1016/j.procs.2019.11.096.S 